\title{
Socio-economic factors do also matter: comments on the article "can climatic factors explain the differences in COVID-19 incidence and severity across the SPANISH regions?: an ecological study"
}

\author{
Pedro Muñoz Cacho', José L. Hernández ${ }^{2,3}$, Marcos López-Hoyos ${ }^{4}$ and Víctor M. Martínez-Taboada ${ }^{3,5^{*}}$ (1)
}

\begin{abstract}
Phosri et al., commented on our previous study about the influence of climate variables at the beginning of the SARS-CoV-2 pandemic in Spain. They showed the impact of the association of gross domestic product (GDP) with the cumulative COVID-19 incidence per $10^{5}$ inhabitants in our country and the rise of several methodologic issues. Here we discussed the main advantages and disadvantages of ecological studies and we advocate to test the hypothesis created in this type of studies using individual-level research designs.
\end{abstract}

In response to the letter submitted by Phosri et al., concerning our paper [1], we agree with the authors that socioeconomic factors may influence the distribution of COVID-19 incidence. However, they surprisingly propose as a proof, the association of gross domestic product (GDP) with the cumulative COVID-19 incidence per $10^{5}$ inhabitants which, due to the lack of adjustment by any confounder factor, may be biased. This lack of controlling for possible confounders is the main criticism that they attribute to our study, that is, they do not apply any of the statistical methods which they propose.

This reply refers to the comment available at https:/doi.org/10.1186/s12940021-00701-6.

*Correspondence: vmartinezt64@gmail.com

${ }^{3}$ Facultad de Medicina, Servicio de Reumatología, University of Cantabria, Hospital Universitario Marqués de Valdecilla, Avda. Valdecilla s/n, 39008 Santander, Spain

${ }^{5}$ Division of Rheumatology, Hospital Marqués de Valdecilla-IDIVAL, Santander, Spain

Full list of author information is available at the end of the article
Focusing on the variable "ultraviolet radiation" (UVR), there could be multiple possible confounder factors, some of them probably unidentified, and some others difficult to quantify. Among them, there are other meteorological variables, socio-economic factors, percentage of older adults, population density, presence of mass transit systems, incidence in neighboring populations, prevalence of highly transmissible variants, cultural and religious variables, etc. However, attempts to control for these variables in ecological studies do not prevent the persistence of the bias inherent to this type of epidemiological design [2-4].

Controlling confounders in ecological studies is more problematic than in individual-level studies. According to Harold Morgenstern "even when all variables are measured accurately for all groups, adjusting for external risk factors may not reduce the ecological bias produced by these risk factors. In fact, it is possible that such ecological adjustment increases the bias" [2]. Recently, Páez et al. [5] have suggested that an ecological study provides evidence that necessarily has to be verified with 
other research designs. A careful reading of this study [5] might also clarify some of the questions rised by Phosri et al.

In addition to the well-known ecological fallacy (or aggregation bias), ecological studies have other limitations, including the lack of adequate data, temporal ambiguity, collinearity, migration across groups, etc. For these reasons, ecological studies contribute to generate hypotheses but not to confirm them. In this sense, the hypotheses arising from ecological studies have to be evaluated in order to verify their biological plausibility, and those that have a sufficiently solid basis according to current knowledge should be contrasted using individual-level designs, such as cohort studies or clinical trials. In this line, in a case-control study, we have recently provided some evidence on the involvement of serum vitamin D levels (influenced by UVR exposure) in hospitalized COVID-19 patients [6]. Another Spanish group has carried out a pilot clinical trial with positive results of the efficacy of vitamin $\mathrm{D}$ supplements in reducing ICU admissions and mortality related to COVID-19 in hospitalized patients [7].

Finally, it should be pointed out that the statement made by Phrosri et al. "Therefore, authors could not conclude that a whether variable, UVR predominantly influences COVID-19 incidence and severity unless other significant variables are included", does not reflect our interpretation of the results, as was clearly expressed in our original manuscript: "Therefore, the design used serves to propose hypotheses that must be corroborated with other epidemiological designs".

Thus, to gain more knowledge about the causes explaining the greater transmissibility and severity of SARS-CoV-2 infection, it is necessary to use individuallevel research designs, mainly randomized clinical trials, rather than trying to control for possible confounders in ecological studies.

\section{Acknowledgements}

Not applicable.

\section{Authors' contributions}

PM and VMT designed the research and collected data; PM analyzed the data; PM, VMT and JLH wrote the manuscript; MLH critically revised the manuscript. All authors discussed the results and contributed to the final paper. The author(s) read and approved the final manuscript.

\section{Funding}

Not applicable.

\section{Availability of data and materials}

National official sources (Ministry of Health; https://www.mscbs.gob.es/) and Spanish Meteorological Agency (upon request: http://www.aemet.es/),

\section{Ethics approval and consent to participate}

Not applicable.

\section{Consent for publication}

Not applicable.
Competing interests

Not applicable.

\section{Author details}

${ }^{1}$ Gerencia de Atención Primaria, Servicio Cántabro de Salud, Santander, Spain. ${ }^{2}$ Department of Internal Medicine, Hospital Marqués de Valdecilla-IDIV AL, Santander, Spain. ${ }^{3}$ Facultad de Medicina, Servicio de Reumatología, University of Cantabria, Hospital Universitario Marqués de Valdecilla, Avda. Valdecilla s/n, 39008 Santander, Spain. ${ }^{4}$ Division of Immunology, Hospital Marqués de Valdecilla-IDIVAL, Santander, Spain. ${ }^{5}$ Division of Rheumatology, Hospital Marqués de Valdecilla-IDIVAL, Santander, Spain.

Received: 3 February 2021 Accepted: 10 February 2021

Published online: 18 February 2021

References

1. Cacho PM, Hernández JL, López-Hoyos M, Martínez-Taboada VM. Can climatic factors explain the differences in COVID-19 incidence and severity across the Spanish regions?: an ecological study. Environ Health. 2020;19: 106. https://doi.org/10.1186/s12940-020-00660-4.

2. Rothman K, Greenland S, TI L. Modern epidemiology. 3rd ed. Philadelphia: Lippincott Williams \& Wilkins; 2008. p. 511-31.

3. Greenland S, Morgenstern H. Ecological bias, confounding, and effect modification. Int J Epidemiol. 1989;18:269-74. https://doi.org/10.1093/ije/1 8.1.269.

4. Greenland S, Robins J. Invited commentary: ecologic studies--biases, misconceptions, and counterexamples. Am J Epidemiol. 1994;139:747-60. https://doi.org/10.1093/oxfordjournals.aje.a117069.

5. Paez A, Lopez FA, Menezes T, Cavalcanti R, Pitta MGDR. A Spatio-Temporal Analysis of the Environmental Correlates of COVID-19 Incidence in Spain. Geogr Anal. 2020. https://doi.org/10.1111/gean.12241, https://doi.org/1 $0.1111 /$ gean. 12241.

6. Hernández JL, Nan D, Fernandez-Ayala M, García-Unzueta M, HernándezHernández MA, López-Hoyos M, et al. Vitamin D Status in Hospitalized Patients with SARS-CoV-2 Infection. J Clin Endocrinol Metab. 2020:dgaa733. https://doi.org/10.1210/clinem/dgaa733.

7. Entrenas Castillo M, Entrenas Costa LM, Vaquero Barrios JM, Alcalá Díaz JF, López Miranda J, Bouillon R, Quesada Gomez JM. Effect of calcifediol treatment and best available therapy versus best available therapy on intensive care unit admission and mortality among patients hospitalized for COVID-19: a pilot randomized clinical study. J Steroid Biochem Mol Biol. 2020;203:105751. https://doi.org/10.1016/j.jsbmb.2020.105751.

\section{Publisher's Note}

Springer Nature remains neutral with regard to jurisdictional claims in published maps and institutional affiliations.

Ready to submit your research? Choose BMC and benefit from:

- fast, convenient online submission

- thorough peer review by experienced researchers in your field

- rapid publication on acceptance

- support for research data, including large and complex data types

- gold Open Access which fosters wider collaboration and increased citations

- maximum visibility for your research: over $100 \mathrm{M}$ website views per year

At $\mathrm{BMC}$, research is always in progress.

Learn more biomedcentral.com/submissions 